\title{
TMPO Gene
}

National Cancer Institute

\section{Source}

National Cancer Institute. TMPO Gene. NCI Thesaurus. Code C105100.

This gene plays a role in nuclear structure. 